УДК 902.64

https://doi.org/10.24852/2587-6112.2021.4.160.168

\title{
СТЕКЛЯННЫЕ УКРАШЕНИЯ ИЗ ЗОЛОТООРДЫНСКОГО ГОРОДА МАДЖАР
}

\author{
(C) 2021 г. Н.П. Курышова
}

Данной работой вводится в научный оборот коллекция украшений из стекла в количестве 153 предметов, происходящая с памятника эпохи Золотой Орды - города Маджар (Буденновский район, Ставропольский край). В исследовании использованы типологические принципы, предложенные М.Д. Полубояриновой. Типологизация вещей показала, что на городище в большом количестве встречаются монохромные бусыс широкими аналогиями и датировками XI-XVIвв. Важное место среди монохромных занимают бусы бирюзового цвета, распространенные более всего в золотоордынских городах Поволжья (середина XIII-XIV вв.). В этих же городах широко распространились и производились пятнистые, глазчатые и полосатые бусы, также занимающие важное место в исследуемой коллекции. Подвески из Маджарской коллекции находят аналогии в кочевнических погребениях золотоорынского времени, встречаются на памятниках Средней Азии. Изучаемая коллекция стеклянных украшений из Маджара демонстрирует прямую связь с ремесленными мастерскими золотоордынских городов Поволжья, традиции которых формировались преимущественно под влиянием хорезмийских и иранских, хотя прослеживается влияние домонгольского стеклодельного ремесла Волжской Булгарии и Руси.

Ключевые слова: археология, Золотая Орда, стеклянные бусы, типология, Маджары, стеклоделие.

\section{GLASS JEWELRY FROM THE GOLDEN HORDE CITY OF MAJAR}

\section{N. P. Kuryshova}

This paper introduces into scientific discourse a collection of 153 glass jewelry items. They take their origin from the Madjar archaeological site of the Golden Horde period (presently - Budyonnovsky district in Stavropol Krai). The study uses typological principles introduced by M.D. Poluboyarinova. A classification of the items demonstrated that large quantities of monochrome beads having numerous counterparts and dated the $11^{\text {th }}-16^{\text {th }}$ centuries are discovered at this archaeological site. An important place among the monochrome beads is occupied by turquoise-colored beads, which were most common in the Golden Horde cities of the Volga region (mid- $13^{\text {th }}-14^{\text {th }}$ centuries). Spotted, eyed and striped beads were also widespread and produced in the same cities. These types of items also form a significant part of the studied collection. It has been found that the pendants from the Madjar collection have counterparts in nomadic Golden Horde burials and are discovered on the sites of Central Asia. The studied collection of glass jewelry from Madjar demonstrates a direct correlation with craft workshops of the Golden Horde cities of the Volga region, whose traditions were formed with the predominant influence of Khorezm and Iranian ones, although the influence of pre-Mongolian glasswork of Volga Bulgaria and Rus has been traced.

Keywords: archaeology, the Golden Horde, glass beads, typology, the Madjar, glassmaking.

В настоящее время в научной литературе постепенно возрастает интерес к археологическому стеклу и особенно к стеклу золотоордынского периода. Государство Золотая Орда (Улус Джучи) существовало немногим более двух столетий, а отдельные города не более четверти века, однако за это недолгое время была создана яркая и пестрая материальная культура, достигнут высокий уровень ремесел, в которые, кроме степных завоевателей, свой вклад внесли самые разные народы Евразии - болгары, русские, мордва, переселенцы из Средней Азии, Крыма. Изготовление стеклянных изделий являлось одним из сложных и высокотехнологичных направлений ремесла, выявление его особенностей дает возможность оценить уровень развития технологий, мастерства ремесленников, а также возможные торговые связи золотоордынских городов.

За XX век при археологических исследованиях нижневолжских городов Золотой Орды было собрано большое количество стеклянных изделий, почти все они изучены и опубликованы (Бусятская Н.Н., 1976; Галкин Л.Л., 1984; Щапова Ю.Л., 1984; Полубояринова М.Д., 1988; Валиулина С.И., 2005). Городу Маджару на Северном Кавказе в этом плане не повезло, археологические экспедиции проводились редко и без четкого плана (Обухов Ю.Д., 2016), практически никогда не публиковался анализ отдельных категорий 
находок и стеклянных изделий в частности. Редкие публикации с кратким представлением результатов археологических исследований не дают полноценного знания о функционировании города и его ремесел. До настоящего момента стеклянные изделия с городища Маджары специально не рассматривались, и представленные ниже материалы впервые вводятся в научный оборот. Существует небольшая, но очень показательная коллекция изделий из стекла, собранная, преимущественно как подъемный материал, на городище в разные годы. Выражаю благодарность Обухову Юрию Дмитриевичу за возможность работы с формирующимся фондом Маджарского археологического музея.

В данной работе исследуются исключительно украшения из стекла - бусы и подвески, численность которых в коллекции 153 экземпляра. Все изделия рассмотрены по типологии, разработанной М.Д. Полубояриновой (Полубояринова, 1988, с. 150). В основу классификации бус положено понятие типа как устойчивого ряда признаков. Технологические особенности изготовления стеклянных бус определяют группы (техника навивки стеклянной массы на металлический стержень; бусы из тянутых трубочек; и проч.), которые, в свою очередь, разделяются на две подгруппы: монохромные и орнаментированные. Первая подгруппа делится на отделы и типы по морфологическому признаку - продольному и поперечному сечениям. Вторая подгруппа подразделяется на разряды по способу орнаментации, а далее на отделы по форме поперечного сечения и на типы по форме в продольном сечении. Внутри вида бусы разделяются по размеру. Учитываются два размера - высота (расстояние между отверстиями) и наибольший диаметр. Третья цифра обозначает диаметр канала бусины.

Все рассматриваемые изделия из Маджара, как бусы, так и подвески, относятся к одной технологической группе, т. к. все они выполнены способом навивки.

Группа I. Одноцветные, изготовленные путем навивки на твердый стержень размягченной стеклянной массы.

Подгруппа А. Неорнаментированные.

Отдел І. Круглые.

Тип 1. Шаровидные (рис. 1: 1; 2: 1) бусы из коричневого, синего и белого глухого стекла. Размеры: 4-4-2; 6-6-2. Найдено 9 экз. Аналогии встречаются в домонгольских памятниках Средней Азии, мордовских могильниках XII-XIV вв. (Алихова, 1948, табл. III, рис. 46).
Белые бусы подобных форм известны в КараКоруме (Левашова, 1966, с. 300, рис. 160, 1 ).

Тип 2. Зонные (рис. 1: 2; 2: 3-6) бусы из непрозрачного и полупрозрачного стекла зеленого, синего и белого, желтого цветов. Размеры: 6-9-3 и 11-15-3. Найдено 15 экз. Аналогии встречаются в Саркеле (Львова, 1959, с. 327), в домонгольских памятниках Средней Азии, в Новгороде в слоях XII-XIII вв. (Щапова, 1956, с. 166), в курганах северо-западной Руси XIII-XIV вв., изредка в поздних мордовских могильниках, золотоордынских городах Поволжья (Бусятская, 1976, с. 40), в Биляре (Валиулина, 2005, рис. 28; 43, 48).

Тип 3. Бочонковидные (рис. 1: 3; 2: 7) из полупрозрачного желтого и темно-синего стекла. Размеры 7-6-2. Найдено 3 экз. Аналогии: бусы подобной формы черные, голубые и желтые встречаются в Саркеле (Львова, 1959, c. 327), Старой Рязани (Монгайт, 1955, с. 176), Кара-Коруме (Левашова, 1965, с. 300, 301), в средневековых слоях Херсонеса и золотоордынских городах Поволжья (Бусятская, 1976, c. 39).

Тип 4. Кольцевидные (рис. 1: 4-5; 2: 8-9) бусы из непрозрачного или полупрозрачного стекла зеленого, желтого или коричневого цвета. Размеры: 3-5-1; 2-8-5. Найдено 19 экз. Аналогии: зеленые, желтые, красные, белые бусы встречаются в домонгольских слоях Афрасиаба, средневековых слоях Херсонеса, курганах северо-западной Руси XIII-XIV вв., золотоордынских городах Поволжья (Бусятская, 1976, с. 39) и в Кара-Коруме (Левашова, 1965, с. 303), в Биляре (Валиулина, 2005, рис. $28 ; 11,13,39)$.

Тип 6. Усеченно-биконические (рис. 1: 6; 2: 10-11) бусы из полупрозрачного темно-синего стекла, непрозрачного стекла бирюзового и зеленого цветов. Размеры: 5-8-2; 4-9-3; 5-7-3; 4-8-3. Найдено 4 эк3. Аналогии: черные, синие, желтые, голубые бусы известны в позднесредневековых слоях Херсонеса, в гдовских курганах, золотоордынских городах Поволжья (Бусятская, 1976, с. 40), мордовских могильниках XIII-XIV вв. (Алихова, 1959, с. 178, табл. 69, рис. 5).

Тип 7. Бусины подцилиндрической формы (рис. 1: 7; 2: 12) в виде навитых друг на друга колец, из непрозрачного голубого, коричневого и полупрозрачного зеленого стекла. Размеры: 7-4-1; 4-6-1; 5-9-1. Найдено 4 экз. Аналогии: бусы голубого цвета встречаются в славянских могильниках (Арциховский, 1930, 


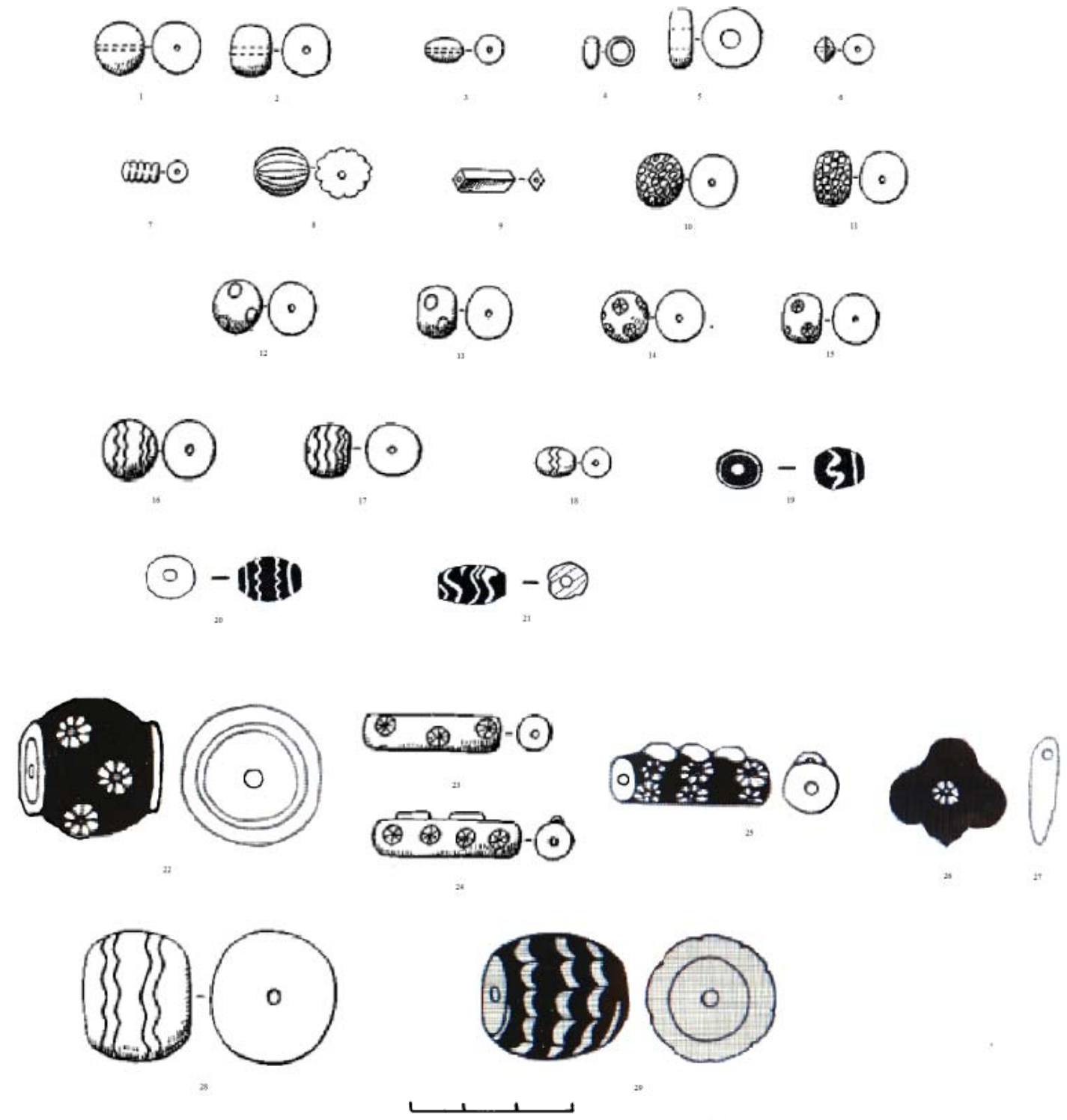

Рис. 1. Стеклянные украшения Маджара

Fig. 1. Jewelry of glasswork from the Golden Horde city of Madjar

c. 140; Щапова, 1972, с. 75), в Биляре (Валиулина, 2005, рис. 28; 14).

Тип 8. Округло-ребристые (рис. 1: 8; 2: 13). Шаровидные или зонные бусины из непрозрачного стекла бирюзового цвета, дополнительно «расчесаны» металлическим инструментом для получения ребристой формы. Размеры 6-9-3 и 11-15-3. Найдено 5 экз. Для периода XIII-XIV вв. круглоребристые бусы из голубого стекла наиболее характерны для среднеазиатских памятников, встречаются в Кара-Коруме (Бусятская, 1976, с. 41), в позднекочевнических погребениях (ФедоровДавыдов, 1966, с. 72).

Отдел II. Граненые.

Тип 1. Четырехгранные. Призматические бусы из непрозрачного бирюзового и полупрозрачного черного, голубого и зеленого стекла (рис. 1: 9; 2: 14-16). Размеры 7-6-2; 14-8-3.
Найдено 12 экз. Аналогии: золотоордынские города Поволжья (Бусятская, 1976, с. 40).

Подгруппа Б. Орнаментированные.

Разряд I. Орнаментированные крошкой разноцветного стекла.

Отдел А. Круглые.

Тип 1. Шаровидные (рис. 1: 10; 2: 17) бусы из непрозрачного черного стекла, орнаментированы крошкой разноцветного стекла: зеленой, желтой, красной, голубой, коричневой. Размеры: 9-9-3; 13-13-3. Найдено 4 экз. Аналогии встречаются в Саркеле в слоях конца XI - начала XII вв. (Львова, 1959, с. 329), в мордовских могильниках XIII-XIV вв. (Алихова, 1948, с. 224), в позднекочевнических курганах Нижнего Поволжья (Г.А. Федоров-Давыдов, 1966, с. 72), в памятниках Северного Кавказа, средневековых слоях Херсонеса, в Болгаре в слоях XII - начала 


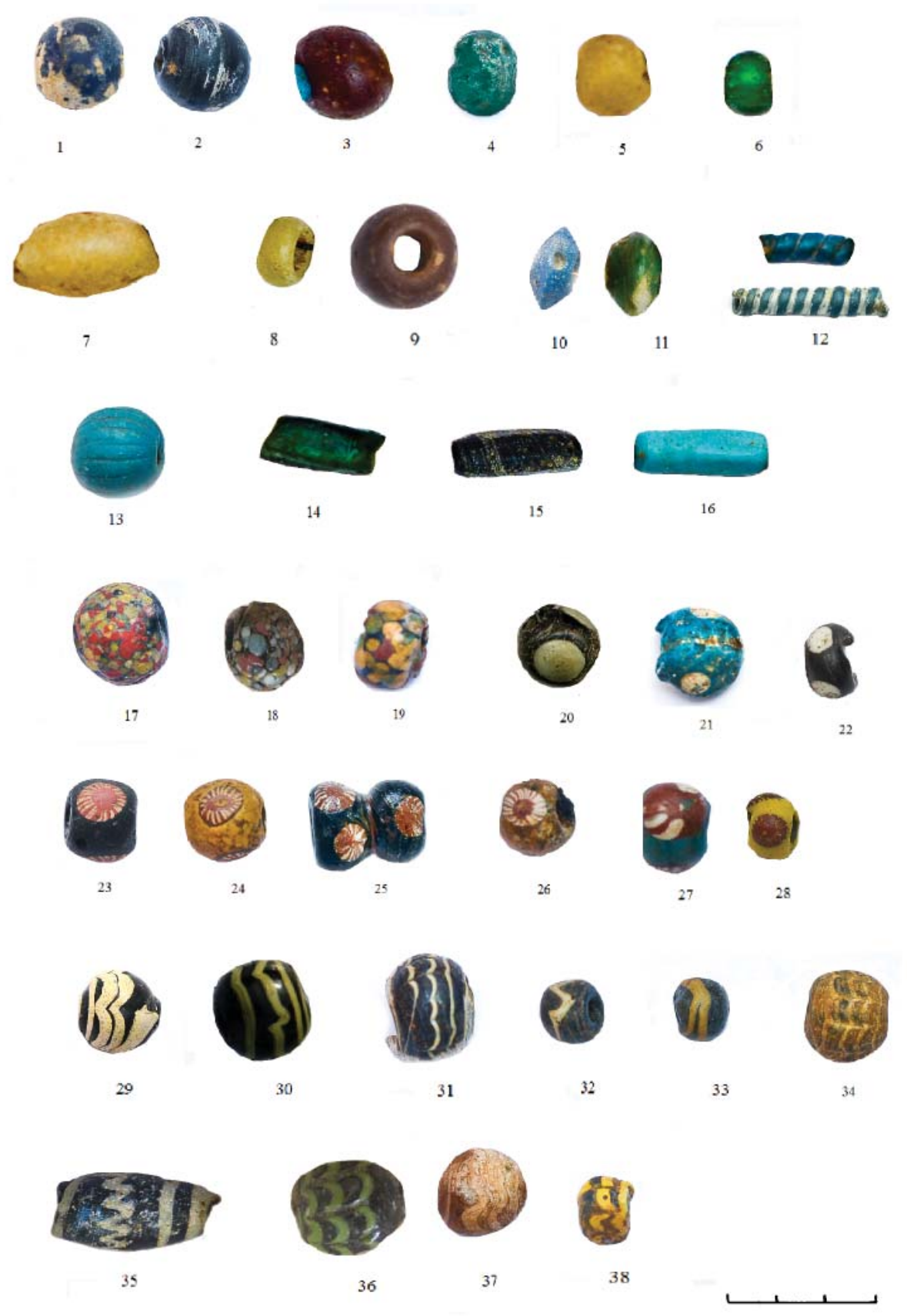

Рис. 2. Стеклянные бусы Маджара

Fig. 2. Glass from the Golden Horde city of Madjar

XIII вв., в курганах северо-западной Руси XIII-XIV вв., в городах Хорезма и золотоордынских городах Поволжья (Бусятская, 1976, c. 41).

Тип 2. Зонные (рис. 1: 11; 2: 18-19) бусы из непрозрачного черного стекла, орнаментированные цветной стеклянной крошкой. Размеры: 9-13-3. Найдено 7 экз. Аналогии: территория и время бытования аналогичны типу 1 , кроме того, зонные бусы, орнаментированные крошкой разноцветного стекла, известны в курганах вятичей (Арциховский, 1930, с. 29).

Разряд II. Пятнистые. Орнамент в виде 3-6 пятен.
Отдел А. Круглые.

Тип 1. Шаровидные (рис. 1: 12; 2: 20-21) бусы из черного непрозрачного стекла, с белыми глазками; бирюзового цвета с темносиними глазками; черного или темно-синего цвета с желтыми глазками. Размеры: 15-16$4 ; 11-2-3 ; 8-9-3$. Найдено 11 экз. Аналогии встречаются в курганах северо-западной и северо-восточной Руси XI-XIII вв. (Фехнер, 1959, рис. 6, 13), в Болгаре в слоях XII-XIII вв. (Валиулина, 2005, с. 93), в могильниках Северного Кавказа, в позднесредневековых мордовских могильниках, памятниках Хорез- 
ма XIII-XIV вв., золотоордынских городах Поволжья (Бусятская, 1976, с. 41).

Тип 2. Зонные (рис. 1: 13; 2: 22) бусы из непрозрачного черного или темно-синего стекла с орнаментом в виде 3-6 пятен белого, желтого или зеленого цвета. Размеры: 5-7-2; 9-11-2; 15-18-4. Найдено 4 экз. Аналогии: территория распространения и время бытования аналогичны типу 1.

Разряд III. Глазчатые. Орнаментированы плоскими глазками с ресничками.

Отдел А. Круглые.

Тип 1. Шаровидные бусины (рис. 1: 14; 2 : 23-24) из черного, желтого и бирюзового непрозрачного стекла с темно-красными глазками с белыми ресничками. Размеры: 5-5-1; 6-7-2; 10-10-3. Найдено 5 экз. Аналогии встречаются в славянских могильниках X-XI вв. (Щапова, 1956, с. 177-178), в Саркеле (Львова, 1959, с. 332), в мордовских могильниках XII-XIV вв. (Алихова, 1959, табл. 69, 2), в позднекочевнических курганах Поволжья (Федоров-Давыдов, 1966, с. 73), в позднесредневековых городах Хорезма и золотоордынских городах Поволжья (Бусятская, 1976, с. 42).

Тип 2. Зонные (рис. 1: 15; 2: 25-28) бусины из черного, голубого и желтого непрозрачного стекла с темно-красными, с белыми ресничками, глазками. Размеры: 9-11-5; 10-12-5. Найдено 13 экз. Территория распространения и время существования аналогичны типу 1.

Разряд IV. Полосатые. Орнамент в виде одной или нескольких волнистых линий.

Отдел А. Круглые.

Тип 1. Шаровидные (рис. 1: 16; 2: 29-30) бусины из непрозрачного темно-синего или черного стекла, украшенные желтыми прямыми или волнистыми линиями. Размеры: 10-10-3; 12-12-3. Найдено 4 экз. Аналогии: бусы черного цвета встречаются в позднесредневековых памятниках Хорезма и золотоордынских городах Поволжья (Бусятская, 1976, c. 42).

Тип 2. Зонные (рис. 1: 17; 2: 31-34) бусы из черного непрозрачного стекла с желтыми или белыми линиями. Размеры: 14-17-5. Найдено 12 экз. Аналогии: встречаются в русских курганах XIII-XIV вв. (Фехнер, 1959, рис. 6, 24), в Новгороде в слоях XIII-XIV вв. (Щапова, 1956, с. 176), в мордовских могильниках (Алихова, 1948, с. 224), в Биляре (Валиулина, 2005, рис. 29, 36-37), в золотоордынских памятниках Хорезма и золотоордынских городах Поволжья (Бусятская, 1976, с. 42).
Тип 3. Бочонковидные (рис. 1: 18-21; 2: 35-36) бусы из черного непрозрачного стекла орнаментированы желтыми, белыми, красными нитями. Изредка встречаются красные или зеленые бусины. Размеры: 13-12-3; 16-11-3; 8-6-2; 10-8-3. Найдено: 7 экз. Аналогии: территория распространения аналогична типу 2.

Среди материала, собранного на городище Маджары, выделяется небольшая группа стеклянных украшений - подвески. В эту категорию входят, во-первых, бусины, которые в силу своего размера или особенности формы должны были носиться как отдельные украшения (на шнурке на шее, в косе или в качестве центральной бусины ожерелья). Во-вторых, кулоны - вытянутые вертикально подвески различной формы, у которых имеется ушко или отверстие, куда пропускается нить или шнурок (Полубояринова, 1988, с. 181). Всего подвесок найдено 20 экземпляров. Как и бусы обычных размеров, мы разделяем подвески по принципам технологии и орнаментации.

Группа I. Одноцветные, изготовленные путем навивки на твердый стержень размягченной стеклянной массы.

Подгруппа А. Неорнаментированные.

Отдел І. Круглые.

Тип 1. Фигурные. (рис. 3: 8-9) Каплевидные и каплевидно-уплощенные подвески из непрозрачного стекла бирюзового цвета. Размеры: 25 мм, 12 мм. Найдено 3 экз. Аналогичные подвески встречаются на Увекском городище.

Подгруппа Б. Орнаментированные.

Разряд II. Подвески с глазчатым узором.

Отдел І. Круглые.

Тип 1. Шарообразная, бирюзовая, украшенная плоскими реснитчатыми бело-красными глазками, вокруг отверстий для нити - рельефный валик из желтого стекла (рис. 1: 22; 3: 1) (1 экз.). Размеры: 40-30-4. Аналогичные подвески встречены на Селитренном и Царевском городищах (Бусятская, 1976, с. 44), в Болгаре и на городище Шехрлик (Полубояринова, 1988 , с. 185).

Тип 2. Цилиндрические.

Вид 1. Одинарные. Подвеска из непрозрачного черного стекла, орнаментирована плоскими реснитчатыми бело-красными глазками (рис. 1: 23; 3: 2). Размеры: 25-10-4. Найден 1 экз.

Вид 2. Двойные цилиндрические подвески из черного или бирюзового стекла с 3 верхними бусинами, украшены плоскими реснитча- 

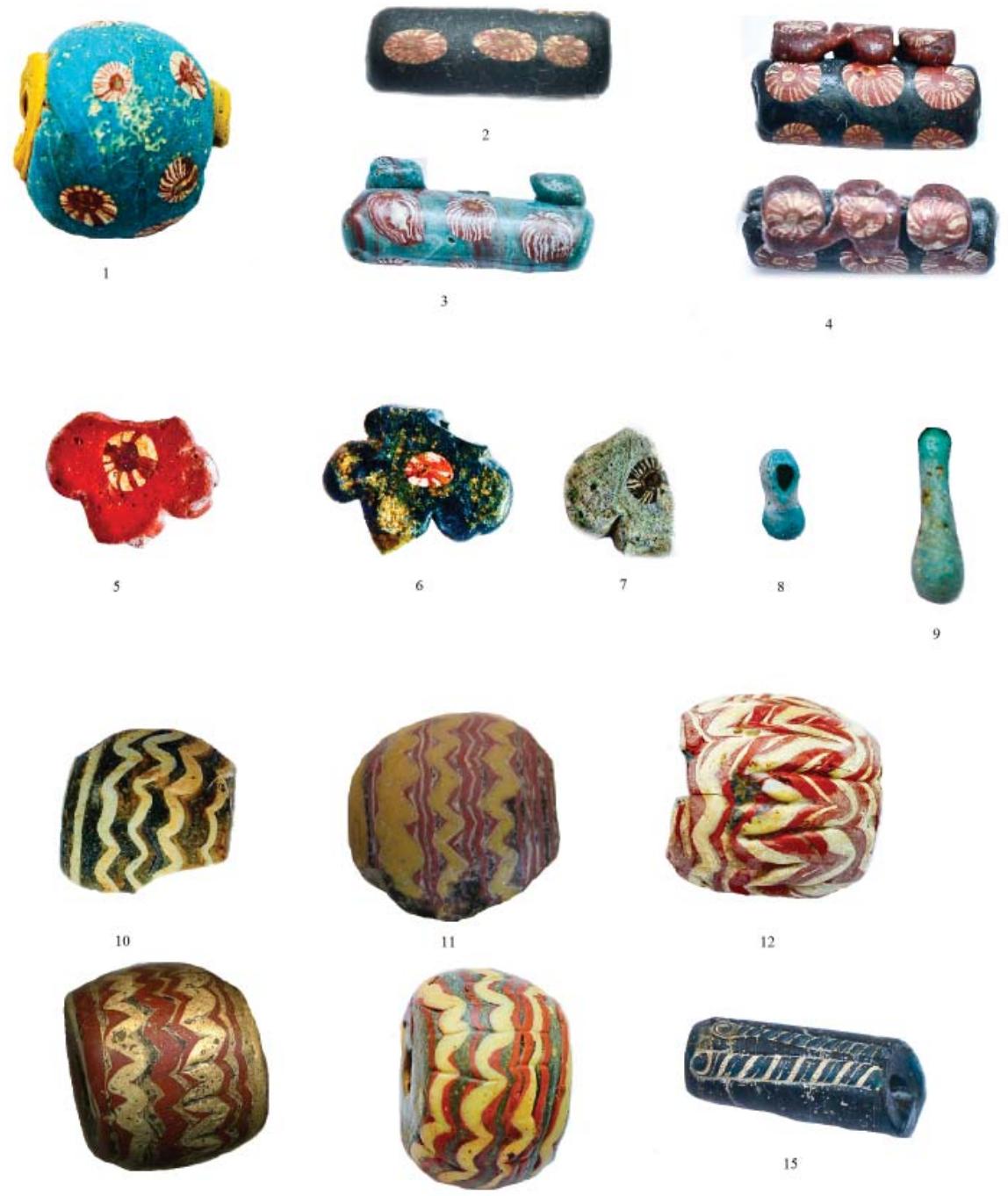

12

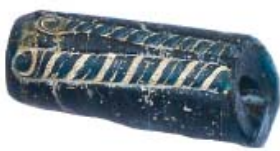

15

14

Рис. 3. Стеклянные подвески Маджара

Fig. 3. Glass pendants from the Golden Horde city of Madjar

тыми бело-красными глазками, с бирюзовой сердцевиной (рис. 1: 24-25; 3: 3-4). Размеры: 30-10-4. Найдено 5 экз. Аналогии для обоих видов встречаются в Болгаре (Полубояринова, 1988, с. 185), на Селитренном, Царевском и Увекском городищах, в развалинах Старого Мерва и в мордовских могильниках. (Бусятская, 1976, с. 44).

Отдел II. Плоские. Фигурные трехчастные подвески-кулоны (канал проходит в верхней части привески). Изготовлены из черного или красного стекла, орнаментированы одним реснитчатым красно-белым глазком (рис. 1: 26; 3: 5-7). Размеры: 28-30, 20, 4. Найдено 3 экз. Аналогии найдены в Хорезме, в Болгаре (Полубояринова, 1988, с. 185), в золотоордынских городах Поволжья (Бусятская, 1976, c. 42 ).
Разряд III. Подвески со спиральной или спирально-волнистой орнаментацией.

Орнамент в виде одной или нескольких волнистых линий.

Отдел I. Круглые.

Тип 1. Зонные подвески из черного непрозрачного стекла, орнаментированы белыми, красно-белыми, зелено-красными нитями. На некоторых хорошо заметны одно- и разнонаправленные «расчесы», которые делались для получения зигзага (рис. 1: 27-28; 3: 10-14). Размеры: 24-24-4; 35-34-4. Найдено 7 экз. Аналогии: встречаются в Болгаре в слоях XII-XIII вв. (Полубояринова, 1988, с. 182), в золотоордынских памятниках Хорезма и золотоордынских городах Поволжья (Бусятская, 1976, с. 42), в кочевнических погребениях Нижнего Поволжья XIII-XIV вв. (Мыськов, 2015 , c. 172). 


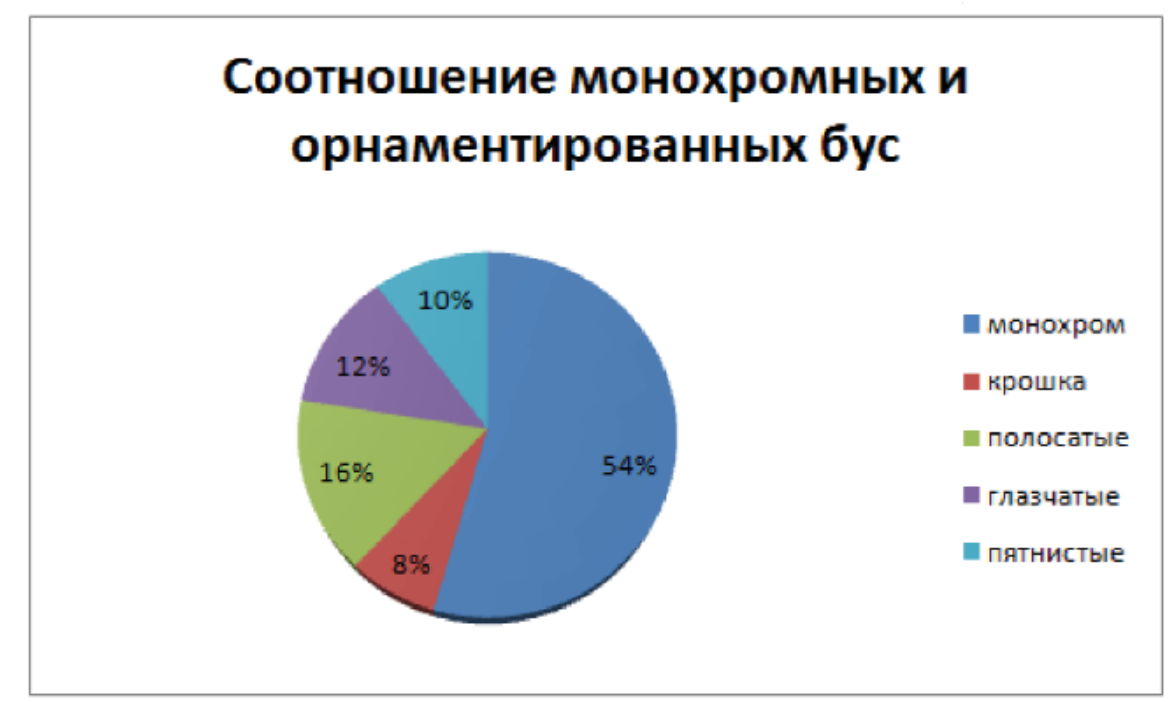

Рис. 4. Диаграмма. Соотношение монохромных и орнаментированных бус

Fig. 4. Graph. The ratio of monochrome and ornamented beads

Разряд IV. Подвески с орнаментацией накладными нитями, образующими различные (не спиральные) узоры.

Отдел І. Круглые.

Тип 1. Цилиндрическая подвеска из непрозрачного черного стекла орнаментирована жгутом, свитым из синего прозрачного и белого непрозрачного стекла (рис. 3: 15). Размеры: 10-5-3. Найден 1 экз. Аналогичные подвески встречаются на Увекском городище.

Как видно из данной типологии, на Маджарском городище в большом количестве (54\%) найдены бусы монохромные: белого, синего, голубого (бирюзового), зеленого, коричневого стекла. Формы бус в основном простые шаровидные, зонные, бочонковидные, кольцевидные. Аналогичные бусы встречены как в среднеазиатских и славянских памятниках XI-XIII вв., так и в памятниках монгольского времени (XIII-XIV вв.). Среди последних они представлены в позднерусских курганах, в Новгороде и на территории городов Золотой Орды.

На долю орнаментированных (пятнистых, глазчатых и полосатых) приходится 46\% от общего количества бус. Аналогии пятнистым широко известны в памятниках XI-XIII вв. на территории Волжской Булгарии, Средней Азии, в небольшом количестве они встречаются на территории древней Руси. В XIII-XIV ВB. основной территорией распространения пятнистых бус становятся золотоордынские города Поволжья. Вместе с тем пятнистые бусы продолжали использоваться на поселениях позднего Средневековья: по большей части в городах Средней Азии и изредка - в русских памятниках.
Аналогии глазчатым бусам известны в памятниках I-XI вв., они получают распространение у многих народов, в том числе и в Восточной Европе. В XIII-XIV вв. ареал глазчатых бус сужается, они встречаются преимущественно в Средней Азии и в золотоордынских городах.

Бусы с орнаментом в виде волнистой линии, часто многократно повторенной в виде спирали, идущей от одного конца отверстия к другому, имеют аналогии в домонгольских памятниках Руси, монгольских памятниках Хорезма и золотоордынских городах Поволжья. На Селитренном городище была раскопана мастерская по изготовлению стеклянных украшений, в первую очередь орнаментированных бус (Галкин, 1984, с. 43). Находки с Маджарского городища имеют среди таких бус прямые аналогии. Подобные же типы бус в XIII-XIV вв. известны главным образом в памятниках Средней Азии и в северных районах Руси, где продолжало существовать местное производство изделий из стекла.

Стеклянные подвески с Маджара имеют аналогии преимущественно из позднекочевнических курганов Поволжья и из мордовских могильников, находившихся под непосредственным влиянием золотоордынской культуры, и среди подвесок из среднеазиатских памятников XII-XIV вв. с многовековыми традициями изготовления подобных украшений. Среди материалов славянских памятников аналогии золотоордынским подвескам неизвестны. Подвески, близкие подвескам второй группы - двойные цилиндрические (отдел 1, тип 2), встречаются в Индии, в памятниках начала нашей эры, в Иране, где они 
датируются XI-XII вв. и позднее (Бусятская, c. 40). Высказано мнение, что внутри таких подвесок могли хранить бумажные амулеты с изречениями из Корана, призванные предохранять от несчастий (Каримова, 2013, с. 37).

Коллекция стеклянных изделий из Маджара является частью интернациональной бижу- терии Евразии XIII-XIV вв. Эти украшения находят аналогии преимущественно в золотоордынских памятниках Поволжья, где они, по-видимому, и изготавливались. Традиции изготовления этой группы изделий восходят к ремеслу средневекового Хорезма, а также домонгольских Волжской Булгарии и Руси.

\section{ЛИТЕРАТУРА}

Алихова А.Е. Старосотенский могильник // Археологический сборник. Вып. 1 / Ред. Ю.В. Готье, Н.Ф. Цыганов, Ю.А. Котков. Саранск: Мордовское книжное издательство. 1948. С. 212-258.

Алихова A.E. Эрзянский могильник XIV в. у с. Гагино // Из древней и средневековой истории мордовского народа / Отв. ред. А.П. Смирнов. Саранск: Мордовское книжное изд-во, 1959. С. 169-184.

Арциховский А.В. Курганы вятичей. М.: РАНИОН, 1930. 222 с.

Бусятская Н.Н. Стеклянные изделия городов Поволжья (XIII-XIV вв.) // Средневековые памятники Поволжья / Отв. ред. А.П. Смирнов. М.: Наука, 1976. С. 38-72.

Валиулина С.И. Стекло Волжской Булгарии (по материалам Билярского городища). Казань: Казанский государственный университет им. В.И. Ульянова-Ленина, 2005. 280 с.

Галкин Л.Л. Стеклодельная мастерская на городище Селитренное // СА. 1984. № 2. С. 213-221.

Каримова Р.Р. Элементы убранства и аксессуары костюма кочевников Золотой Орды (типология и социокультурная интерпретация) / Археология евразийских степей. Вып. 16. Казань: Институт истории им. Ш. Марджани, 2013. 212 с.

Левашова В.П. Бусы из Кара-Корума // Древнемонгольские города / Отв. ред. С.В. Киселев. М.: Наука. 1965. С. 297-307.

Львова 3.А. Стеклянные браслеты и бусы из Саркела - Белой Вежи // МИА. № 75 / Отв. ред. М.И. Артамонов. М.-Л.: Изд-во АН СССР, 1959. С. 307-332.

Монгайт А.Л. Старая Рязань / Материалы и исследования по археологии древнерусских городов. Т. 4. / МИА. № 49. М.: АН СССР, 1955. 228 c.

Мыськов Е.П. Кочевники Волго-Донских степей в эпоху Золотой Орды. Волгоград: РАНХиГС, 2015. $484 \mathrm{c}$.

Обухов Ю.Д. Историография археологического изучения городища Маджары // Материалы V Международной Нижневолжской археологической конференции / Отв. ред. П.М. Кольцов. Элиста: Изд. Калмыцкого университета, 2016. С. 249-254.

Полубояринова М.Д. Стеклянные изделия Болгарского городища // Город Болгар: Очерки ремесленной деятельности / Отв. ред. Г.А. Федоров-Давыдов. М.: Наука, 1988. С. 151-219.

Полубояринова М.Д. Стеклодельная мастерская XIV в. в городе Болгаре // PA. 2006. № 4. С. 57-72.

Федоров-Давыдов Г.А. Кочевники Восточной Европы под властью золотоордынских ханов. Археологические памятники. М.: Изд-во МГУ, 1966. 276 с.

Фехнер М.В. К вопросу об экономических связях древнерусской деревни // Очерки по истории русской деревни X-XIII вв. / Труды ГИМ. Вып. 33 / Ред. Б.А. Рыбаков. М: Советская Россия. 1959. C. 149-224.

Щапова Ю.Л. Стеклянные бусы древнего Новгорода // Труды Новгородской археологической экспедиции. Т. І / МИА. № 55 / Отв. ред. А.В. Арциховский и Б.А. Колчин. М.: АН СССР, 1956. С. 164-179.

Щапова Ю.Л. Стекло Киевской Руси. М.: МГУ, 1972. 216 с.

Щапова Ю.Л. Химико-технологическое изучение стекол из мастерской на городище Селитренное // CA. 1984. № 2. С. 222-224.

\section{Информация об авторе:}

Курышова Наталья Павловна, аспирант, Казанский федеральный университет (г. Казань, Россия); snejka15@yandex.ru

\section{REFERENCES}

Alikhova, A. E. 1948. In Gotie, Yu. V., Tsyganov, N. F., Kotkov, Yu. A. (eds.). Arkheologicheskii sbornik. (Archaeological Collection of Papers. 1. Saransk: "Mordovskoe knizhnoe izdatel'stvo" Publ., 212-258 (in Russian). 
Alikhova, A. E. 1959. In Smirnov, A. P. (ed.). Iz drevnei i srednevekovoi istorii mordovskogo naroda (Essays on Ancient and Medieval History of the Mordva People). Saransk: Mordovian Book Publ., 169-184 (in Russian).

Artsikhovskii, A. V. 1930. Kurgany viatichei (Burial Mounds of the Viatichi). Moscow: "RANION" Publ. (in Russian).

Busiatskaia, N. N. 1976. In Smirnov, A. P. (ed.). Srednevekovye pamiatniki Povolzh'ia (Medieval Sites from the Volga Region). Moscow: "Nauka" Publ., 73-107 (in Russian).

Valiulina, S. I. 2005. Steklo Volzhskoi Bulgarii (po materialam Biliarskogo gorodishcha) (Glass of Volga Bulgaria: by materials of the Bilyar Fortified Settlement). Kazan: Kazan State University (in Russian).

Galkin, L. L. 1984. In Sovetskaia Arkheologiia (Soviet Archaeology) (2), 213-221 (in Russian).

Karimova, R. R. 2013. Elementy ubranstva i aksessuary kostiuma kochevnikov Zolotoi Ordy (tipologiia i sociokul'turnaia interpretatsiia) Elements of dressing and costume accessories of Golden Horde nomads (typology, social and cultural interpretation). Series: Arkheologiia evraziiskikh stepei (Archaeology of the Eurasian Steppes) 7. Kazan: Institute of History named after Shigabuddin Mardzhani, Tatarstan Academy of Sciences; Samara Municipal Institute for Public Administration (in Russian).

Levashova, V. P. 1965. In Kiselev, S. V. (ed.). Drevnemongolskie goroda (Early Mongol Towns). Moscow: "Nauka" Publ., 297-307 (in Russian).

L'vova, Z. A. 1959. In Artamonov, M. I. (ed.). Materialy i issledovaniia po arkheologii SSSR (Materials and Research in the USSR Archaeology) 75. Moscow; Leningrad: the USSR Academy of Sciences, 307-332 (in Russian).

Mongait, A. L. 1955. In Materialy i issledovaniia po arkheologii drevnerusskikh gorodov (Materials and Studies on the Archaeology of Old Russian Towns) 4. Series: Materialy i issledovaniia po arkheologii SSSR (Materials and Studies in Archaeology of the USSR) 49. Moscow: Academy of Sciences of the USSR (in Russian).

Mys'kov, E. P. 2015. Kochevniki Volgo-Donskikh stepei v epokhu Zolotoi Ordy (Nomads of the Volga-Don Steppes in the Golden Horde Period). Volgograd: "RANKhiGS" Publ. (in Russian).

Obukhov, Yu. D. 2016. In Koltsov, P. M. (ed.). Materialy V Mezhdunarodnoi Nizhnevolzhskoi arkheologicheskoi konferentsii (Proceedings of the $5^{\text {th }}$ International Lower Volga Archaeological Conference). Elista: Kalmyk State University, 249-254 (in Russian).

Poluboiarinova, M. D. 1988. In Fedorov-Davydov, G. A. (ed.). Gorod Bolgar. Ocherki remeslennoi deiatel'nosti (City of Bolgar. Essays on Handicrafts). Moscow: "Nauka" Publ., 151-219 (in Russian).

Poluboiarinova, M. D. 2006. In Rossiiskaia Arkheologiia (Russian Archaeology) (4), 57-72 (in Russian).

Fedorov-Davydov, G. A. 1966. Kochevniki Vostochnoi Evropy pod vlast'iu zolotoordynskikh khanov: Arkheologicheskie pamiatniki (East-European Nomads under the Golden Horde's Khans: Archaeological Sites). Moscow: Moscow State University (in Russian).

Fekhner, M. V. 1959. In Rybakov, B. A. (ed.). Ocherki po istorii russkoi derevni X-XIII vv. (Sketches on History of the Russian Village of $10^{\text {th }}-13^{\text {th }}$ Centuries). Series: Trudy Gosudarstvennogo istoricheskogo muzeia (Proceedings of the State Historical Museum) 33. Moscow: "Sovetskaia Rossiia” Publ., 149-173 (in Russian).

Shchapova, Yu.L. 1956. In Artsikhovskii,A. V., Kolchin, B.A.(eds.). Trudy Novgorodskoi arkheologicheskoi ekspeditsii (Proceedings of the Novgorod Archaeological Expedition) 1. Series: Materialy i issledovaniia po arkheologii SSSR (Materials and Research in the USSR Archaeology) 55. Moscow: Academy of Sciences of the USSR Publ., 165-179 (in Russian).

Shchapova, Yu. L. 1972. Steklo Kievskoi Rusi (Glass of Kievan Rus). Moscow: Lomonosov Moscow State University (in Russian).

Shchapova, Yu. L. 1984. In Sovetskaia Arkheologiia (Soviet Archaeology) (2), 222-224 (in Russian).

\section{About the Author:}

Kuryshova Natalya P. Kazan (Volga Region) Federal University. Kremlyovskaya St., 18, Kazan, 420000, the Republic of Tatarstan, Russian Federation; snejka15@yandex.ru 